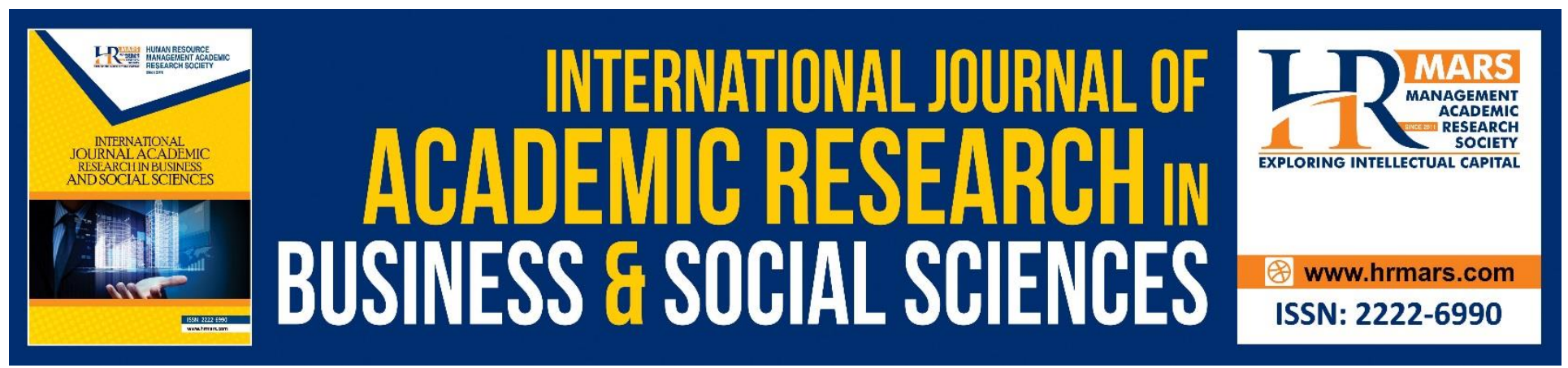

\title{
Three Main Components for Ulul Albab Teachers' Professional Development Programme Theory
}

Nor Adzimah Subirin, Nor Hayati Alwi, Fathiyah Mohd Fakhruddin, Umi Kalthom Abdul Manaf, Siti Suria Salim, Siti Aishah Hassan, Shamsudin Othman, Nurul Jawahir Mohd Ali

To Link this Article: http://dx.doi.org/10.6007/IJARBSS/v8-i10/4795 DOI: $10.6007 /$ IJARBSS/v8-i10/4795

Received: 19 Sept 2018, Revised: 21 Oct 2018, Accepted: 29 Oct 2018

Published Online: 10 Nov 2018

In-Text Citation: (Subirin et al., 2018)

To Cite this Article: Subirin, N. A., Alwi, N. H., Fakhruddin, F. M., Manaf, U. K. A., Salim, S. S., Hassan, S. A., ... Ali, N. J. M. (2018). Three Main Components for Ulul Albab Teachers' Professional Development Programme Theory. International Journal of Academic Research in Business and Social Sciences, 8(10), 1005-1019.

Copyright: (C) 2018 The Author(s)

Published by Human Resource Management Academic Research Society (www.hrmars.com)

This article is published under the Creative Commons Attribution (CC BY 4.0) license. Anyone may reproduce, distribute, translate and create derivative works of this article (for both commercial and non-commercial purposes), subject to full attribution to the original publication and authors. The full terms of this license may be seen

at: http://creativecommons.org/licences/by/4.0/legalcode

Vol. 8, No. 10, 2018, Pg. 1005 - 1019

http://hrmars.com/index.php/pages/detail/IJARBSS

JOURNAL HOMEPAGE

Full Terms \& Conditions of access and use can be found at http://hrmars.com/index.php/pages/detail/publication-ethics 


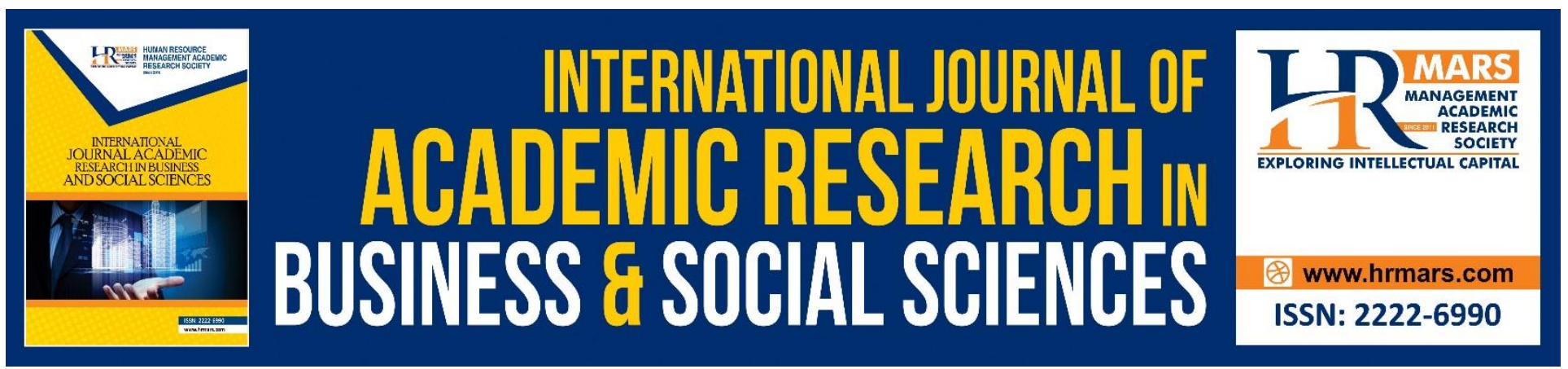

\title{
Three Main Components for Ulul Albab Teachers' Professional Development Programme Theory
}

\author{
Nor Adzimah Subirin, Nor Hayati Alwi, Fathiyah Mohd Fakhruddin, \\ Umi Kalthom Abdul Manaf, Siti Suria Salim, Siti Aishah Hassan, \\ Shamsudin Othman, Nurul Jawahir Mohd Ali
}

Faculty of Educational Studies, University Putra Malaysia, 43400 UPM Serdang, Selangor Darul

Ehsan, Malaysia

\begin{abstract}
The role of teachers as purveyors of knowledge and values is crucial to improve the quality of educational processes which leads to the excellence outcomes. The quality of education directly needs the teachers to play their roles. Therefore, the curriculum of education and preparation of teachers should be considered as the central and most crucial in the reconstruction of any educational system. In the context of Ulul Albab, objectives, mission and vision have been drawn up beautifully to achieve the aim of having a generation who is able to use their mind and heart to understand the essence of life based on strong foundation of Al-Quran epistemology. It is therefore, the students of Ulul Albab program that need to be educated, guided, facilitated, and monitored properly to prepare them as Ulul Albab generation. Hence, teachers are expected to play their role as a group who will be responsible to assist these students. This research has been concerned on teachers of the Ulul Albab program as the key implementer of Ulul Albab curriculum. The purpose of this research is to examine the components of professional development (PD) theory for teachers of Ulul Albab program regardless of field of expertise, religious or academic. Six experts and prominence in various fields have been interviewed from purposeful sampling method, in order to investigate the relevancy of developing teachers' professional development for Ulul Albab teachers. Open coding grounded theory approach by using Qualitative Data Analysis (QDA) Software Atlas ti has been chosen to analyse the data, whereby, the theory develops from the data as it is collected and analysed inductively. In-depth interview method has been using for collecting data and the recorded interviews were transcribed verbatim. The findings have shown that there are three main components; the Input, the Process/Mechanism and the Outcome in which several elements have been drawn up from the findings such as the selection of the right teachers, teachers' training (preservice and in-service) model, and the nature of Ulul Albab teachers. Each component that represents every element in the findings will be treated as the foundation in developing Ulul Albab Teachers' Professional Development Programme Theory. From the discussion, the experts collaboratively agree
\end{abstract}


INTERNATIONAL JOURNAL OF ACADEMIC RESEARCH IN BUSINESS AND SOCIAL SCIENCES Vol. 8, No. 10, Oct. 2018, E-ISSN: 2222-6990 @ 2018 HRMARS

that teachers' professional development is necessary to prepare teachers with certain characteristics. In a nutshell, it is crucial to train the teachers with a systematic and dynamic professional development according to the concept of Ulul Albab, for the sake of moulding future generation that would be the frontliner of Muslim civilization in the country.

Keywords: Basic Components, Professional Development Theory, Teachers of Ulul Albab

\section{INTRODUCTION}

It is evident that a sufficient number of competent and professional teachers are required in order to improve the quality of educational processes, which leads to the excellence outcomes. In fact, the quality of education directly needs the teachers to play their roles. The role of teachers as purveyors of knowledge and values and as community leaders responsible for the future of the young (UNESCO, 2003), is expected to be highlighted accordingly. Therefore, the education and preparation of teachers should be considered as the central and most crucial in the reconstruction of any educational system (Baloch, 1980).

Teachers are the ones who work and collaborate directly with students. They are responsible to interpret and shape curricular goals and theoretical ideas into classroom practice and create the environment for learning. Teachers' knowledge, skills, attitudes, and dispositions have direct and serious implications for the success of the students they teach (Timperley, Wilson, Barrar \& Fung, 2007). Thus, Teachers' Professional development refers to many types of educational experiences related to teacher's works as mean to upgrade their profession as a teacher. It is a strategy, whereby, a teacher continually becomes a leaner in making them excel in their teaching field. According to Hayes (2010) professional development is the only school systems' strategy that to strengthen educators' performance levels. He added, professional development is also the only way educators can learn so that they have certain quality to better their performance and raise student achievement. From this standpoint, professional development represents an enormous investment in the development of human capital, directed at ensuring that the teaching and learning in the schools is according to the goal set.

Teacher's training or professional development in most countries entails several course work and students teaching experience, which is somehow, not adequate to produce sufficient quality teachers in certain area of education. In other words, teacher's professional development program should be design according to the need of a particular educational program. In the context of Ulul Albab program, teachers are expected to acquire specific quality within their professionalism more than just expert in certain of fields.. For the student to get proper guidance and role model, sufficient quality of Ulul Albab teachers should be address carefully. Eventually, Ulul Albab program which upholds Islamic Principles and Belief as the pillars is expected to have teachers who are aware of the concept and ideas of Ulul Albab, whereby, this paradigm can be instilled into the mind and the soul of their students. According to Ahmed Shami (1980), most of the existing teacher training programmes in Muslim countries are geared to help in developing the mind and body only; meanwhile, 'spiritual education' is nowhere to appear as a goal of education. The adaptation of Western form of teacher training into most of the Muslim countries, effected the result of corrupted educational system toward secularism and separable entity. It is therefore, Ulul Albab Professional Development Program is necessary to be established in order to prepare the teachers to achieve the 
INTERNATIONAL JOURNAL OF ACADEMIC RESEARCH IN BUSINESS AND SOCIAL SCIENCES

Vol. 8, No. 10, Oct. 2018, E-ISSN: 2222-6990 @ 2018 HRMARS

required standard within the program. the preparation for teachers for the Ulul Albab program in terms of professional development training would be the yardstick towards Ulul Albab teachers' quality to procreate the Ulul Albab generation.

\section{Ulul Albab Program}

Ulul Albab program has been recognized as a new educational program (Nor Hayati et al., 2015) which is based on integrated curriculum by upholding three main approaches namely Quranic, Encyclopaedic, and ljtihadic (Ministry of Education Malaysia portal, 2017). Each approach addresses specific criteria that would be introduced to the students of Ulul Albab program. Basically, there are three types of government schools that currently have been using the curriculum of Ulul Albab program, such as MRSM Ulul Albab, SMKA Tahfiz Model Ulul Albab, and SBP Ulul Albab. Even though the objective, mission and vision are varied to every type of Ulul Albab schools, they are aiming of the same main goal, whereby, to produce Ulul Albab experts in various fields that well versed in the field of religion as well as having deep understanding of al-Quran and Sunnah (Ministry of Education Malaysia portal, 2017).

Despite of solid program's goal and mission, it cannot be achieved easily without urging teachers to play their roles. Teacher as one of the key implementer of a program or curriculum needs to be addressed with specific role and criteria (Fathiyah et al., 2017). Al-Ghazali proposed a professional code of ethics for teachers, as he urged the teachers to be practiced of what they preach, and be example to their pupils and community (Nabil, 2000). As exemplars to the pupils, teachers are necessary to be prepared with certain and specific quality and criteria according to the goal of Ulul Albab program. Therefore, the study of Ulul Albab Teachers' Professional development programme would help to address important elements in order to produce teachers with appropriate quality according to Ulul Albab concept. This study also is to fill in the gap of previous research which only discussed Ulul Albab teachers' matter in general (Mohd Kamal Hassan, 2010; Sidek Baba, Mohamad Johdi, Tareq \& Ridwan, 2015; Mohd Shahril \& Sidek Baba, 2013; Arniyuzie, 2015) and evaluation of Ulul Albab programs conducted (Rohaizan, Zulkifli, Abdul Hakim \& Syed Mohd Azmi; Umi Kalthom, Nurul Fitriah, Ady Hameme, Fadzilah \& Hafizah, 2014).

\section{Ulul Albab Teacher Professional Development: A New Type of Broad-Based Integrated and Holistic Professional Development}

Guskey (2000) states, "One constant finding in the research literature is that notable improvements in education almost never take place in the absence of professional development." He added, "professional development programs are systematic efforts to bring about change in classroom practices of teachers, in their attitudes and beliefs, and in the learning outcomes of students" (Guskey, 2002). Professional development is defined as "the process of improving staff skills and competencies needed to produce outstanding educational results for students" (Hassel, 1999) which is mostly important to make the teachers aware of their profession role and responsibility. It means, professional development is very important for teachers to be called as professional in their field. The professional development is the key to meeting today's educational demands (Stacey, 2005). 
For Muslim society, education is demanded to produce pious devotees toward the Almighty Allah SWT and, honourable social individuals that are able to balance their life between worldly and lifeafter matters. Eventually, in the context of Ulul Albab program, integrating the whole education of teachers should take precedence over the limited concept of producing Ulul Albab generation. According to Tajul Ariffin, (2002) integration concept of education is referring to naqli (wahy) knowledge above aqli knowledge integrated with multidiscipline and knowledge, whereby, the aim is to generate Ummah affirms with tauhid and aqidah. According to Lilia (2011), the discovery of science knowledge under control of wahyu (naqli) will procreate scientist who profess the oneness of Allah (Tawheed). She added that the profession will motivate them to play their role as slaves of Allah and vicegerent of Allah in the field of science and technology. The teachers in the Ulul Albab program, therefore, really need to be facilitated and guided toward the integration of naqli and aqli knowledge rather than be trained to become an expert in specific subject matter.

Basically, Ulul Albab program is a new integrate-based educational program of the existing programs (Science streaming) and the religious program including Tahfiz Al-Quran (Mohd.Sharil \& Sidek, 2013). That is to say, Ulul Albab program aims to produce Muslim scientist who are expert in science and religious knowledge as well as able to grasp the hikmah from the verse (ayah) of AlQuran. According to Nor Hayati (2011), to develop Muslim scientist accordance to Islamic science teaching and education, integrated development strategy is required to be addressed, as follows;

i. Teaching and education that emphasize the development of human as a whole

ii. The inculcation of true knowledge is knowledge that can change the heart of man to believe in Allah

iii. The inculcation of integrated knowledge between aqli and naqli knowledge

iv. The inculcation of knowledge that has undergone Islamization process of knowledge as a process that changes the perspective of aqli and naqli knowledge

$v$. The use of science terms from the framework of knowledge or Islamic civilization

vi. Interesting and effective teaching

vii. Co-curriculum activities inclined towards Islam

viii. The atmosphere that stimulates the development of faith

ix. The existence of a divine education system

x. The existence of systems and evaluation tools that assess the overall development of human beings

The above strategies could be use as guideline in developing professional development for the Ulul Albab program. Consequently, in most Muslim countries, teacher training (program) models are taken from the West (Ahmed Shami, 1980), which perhaps could affect the outcome of the respective program. The adaptation from the West is something normal. But yet, Ulul Albab is expected to free itself from the influence of any kind of the Western models. According to Abdul Ghafur (1980), it is vital that a new scheme of training (program) be devised through intensive training in the fundamental of Islam, but also receives training in other modern branches of learning. He added, there is no dichotomy between the religious and the secular or the intuitive and the 
INTERNATIONAL JOURNAL OF ACADEMIC RESEARCH IN BUSINESS AND SOCIAL SCIENCES

Vol. 8, No. 10, Oct. 2018, E-ISSN: 2222-6990 @ 2018 HRMARS

intellectual, Tawheed (monotheism) implies that there is an essential unity in all knowledge which derives from the Al-Quran and As-Sunnah.

\section{Problem Statement}

Teachers of the Ulul Albab program has become an issue. Based on several studies, the quality of Ulul Albab teachers has not yet achieved the standard that is wanted. Research done by Muhammad Abdullah et al (2014) and Umi et al. (2014) in separate MRSM Ulul Albab advocated that the quality of teachers need to be improved and refined as the teachers do not seem to be able to monitor their students to understand the meaning of Al-Quran they memorized. Therefore, Nor Hayati (2015) urgently suggests that the teachers should oblige to Ulul Albab quality, and then only will they be able to become role model and agents of change towards the achievement of the aims of Ulul Albab program. She further claimed that to develop teachers of those qualities, teachers' professional development programs for Ulul Albab pre-service and in-service teachers become important. It would be good to say that, Ulul Albab students' quality is the reflection of the Ulul Albab teachers' quality. Kamal Hassan (2010) and Nor Hayati et al. (2015) agree that the programs per se should be reinterpreted according to Islamic worldview.

To prepare a specific or special professional development for specific educational seems to be necessary in order to gain optimum result. Research done by Arniyuzie (2015) found that there is a need to develop and improve teachers' quality of Ulul Albab program specifically inculcating the element of Quranic, Encyclopaedic and Ijtihadic. These elements somehow need to be blended and integrated well within the system, either for the students or the teachers. Eventually, the understanding of integration concept of the program seems unclear specifically among the teachers. Supported from a study done by Sidek Baba et. al (2015) showed that there is insufficient understanding upon the integration between sciences and naqli (revealed) knowledge among the teachers of Ulul Albab program, which needs to be discovered in depth. Thus, the program needs its special teachers professional program that may induce specific curriculum that suit the objectives of the program.

This study, therefore, is to explore scholars' view regarding this need and how important teachers' professional development for Ulul Albab program from the viewpoints of these experts in various field. This will strengthen and energize the objective of this study.

\section{Objectives of Study}

The purpose of this study is to generate and validate the basic components of theory for Ulul Albab Teachers' Professional Development Program

\section{METHODOLOGY}

A qualitative study was carried out to investigate the aspects of Professional Development based on the opinions and views of the experts regarding Ulul Albab Teachers' Professional Development Program. It is to examine their viewpoint on the main components of theory for Teachers' Professional Development Program in shaping the wholeness of the Ulul Albab program particularly in producing an Ulul Albab generation. The study was using open coding Grounded Theory approach in analyzing the data that has been collected inductively, in which, according to 
INTERNATIONAL JOURNAL OF ACADEMIC RESEARCH IN BUSINESS AND SOCIAL SCIENCES Vol. 8, No. 10, Oct. 2018, E-ISSN: 2222-6990 @ 2018 HRMARS

Creswell (2009), the researcher derives a general, abstract theory of process, action, or interaction grounded in the views of participants in a study. Precisely, Strauss \& Corbin (1990) claimed that a grounded theory is a theory which is acquired inductively from research that studied the phenomenon which it represented. The data of the findings have been analyzed only at the level of open coding.

The respondents of this research were selected through purposive sampling technique. The sampling was also using snowballing technique based on certain criteria, whereby, some respondents of this study have been suggested by previous respondent. There are six experts who have been chosen from various field of expertise that are well-known in their contribution to the society, specifically Muslim society. Moreover, most of the experts are well-versed in the concept of Ulul Albab, whereby they have written articles and books regarding the Ulul Albab in general. The table 1 below is the list of the respected experts for this study.

Table 1: List of Respondents

\begin{tabular}{|l|l|l|l|}
\hline NO & NAME OF EXPERTS & INSTITUTIONS & ARTICLES/BOOKS \\
\hline 1 & $\begin{array}{l}\text { Tan Sri Professor } \\
\text { Dr. Mohd Kamal } \\
\text { Hassan }\end{array}$ & $\begin{array}{l}\text { Distinguished Professor, } \\
\text { Centre For Islamization, } \\
\text { International Islamic } \\
\text { University Malaysia }\end{array}$ & $\begin{array}{l}\text { The Author of An Article: } \\
\text { The Return to The Qur Anic } \\
\text { Paradigm Of Development And } \\
\text { Integrated Knowledge: The Ulul } \\
\text { Al-Albab Model. Intelectual } \\
\text { Discourse }\end{array}$ \\
\hline 2 & $\begin{array}{l}\text { Datuk Dr. Zulkifli } \\
\text { Mohd Al-Bakri }\end{array}$ & $\begin{array}{l}\text { Federal Mufti, Pejabat } \\
\text { Mufti Wilayah Persekutuan } \\
\text { Kuala Lumpur }\end{array}$ & $\begin{array}{l}\text { Ulul albab: kngens dan } \\
\text { pengertian menurut syarak }\end{array}$ \\
\hline 3 & $\begin{array}{l}\text { Professor Dr. Malik } \\
\text { Badri }\end{array}$ & $\begin{array}{l}\text { Universiti } \\
\text { Antarabangsa Malaysia }\end{array}$ & $\begin{array}{l}\text { Well-known Muslim psychologist, } \\
\text { well-versed on Ulul Albab }\end{array}$ \\
\hline 4 & Dr. Mat Rofa Ismail & $\begin{array}{l}\text { Former Profesor Madya of } \\
\text { Science Faculty, UPM }\end{array}$ & $\begin{array}{l}\text { Ulul Albab Ajaibnya } \\
\text { Semesta }\end{array}$ \\
\hline 5 & $\begin{array}{l}\text { Dr. Danial Zainal } \\
\text { Abidin }\end{array}$ & $\begin{array}{l}\text { Medical Doctor, Preacher } \\
\text { and TV personality }\end{array}$ & $\begin{array}{l}\text { Menjadi Ulul Albab Generasi } \\
\text { Genius Bertaqwa }\end{array}$ \\
\hline 6. & $\begin{array}{l}\text { Professor } \\
\text { Emeritus } \\
\text { Dr.Hashim Musa }\end{array}$ & $\begin{array}{l}\text { Former Professor of } \\
\text { Language Faculty, UPM }\end{array}$ & $\begin{array}{l}\text { Well-known author of Hang } \\
\text { Tuah : Catatan Okinawa }\end{array}$ \\
\hline
\end{tabular}

Open-ended questions have been used and discussions were conducted based on the interview guide (protocol) that have been constructed and validated. Data collected were transcribed and analysed using the software Atlas ti. Open coding of grounded theory approach in this study involves searching and pointed out the concepts behind the actualities of the data. Coding may be described as the deciphering or interpretation of data and includes the naming of concepts and also explaining and discussing them in more detail (Böhm, 2004). The codes will be pulled together and 
INTERNATIONAL JOURNAL OF ACADEMIC RESEARCH IN BUSINESS AND SOCIAL SCIENCES

Vol. 8, No. 10, Oct. 2018, E-ISSN: 2222-6990 @ 2018 HRMARS

categorise a series of otherwise discrete events, statements (Charmaz, 1983) which has been identify in the data.

\section{FINDINGS AND DISCUSSION}

This research will be based from the findings of a research done by Nor Hayati $(2002,2005)$ with the Theory of Holistic and Balance Human Development in Science Education as the theoretical framework. Three main components of the said theory which were identified (Nor Hayati, 2015) as the Input, the Mechanism (Process), and the Outputwill be served as main components of building a theory for Ulul Albab Teachers' Professional Development Program (TPDP). From the data, few elements have been categories into these three components such as a selection of the right teachers which discusses on teacher's traits; teachers' training model which discusses the training features and the nature of Ulul Albab teachers that possess certain personality and quality after going through the training process. These three categories were generated and validated as the structural components of the theory (Beauchamp, 1975; Nor Hayati, 2002, 2005, 2015).

Eventually, the Theory of Holistic and Balance Human Development in Science is deemed appropriate to act as a guideline for the professional development of Ulul Albab teachers as both discussed matters in term of Islamic perspective as well as scientific perspective. According to Nor Hayati (2015) both theories emphasized on the holistic development of human beings based on the belief and devotion to Allah s.w.t or tawhid, which is very crucial in developing a theory for Muslim professional development.

From the findings, the categories of these three components have been verified and validated by the six experts through in-depth interviews. The findings and discussion will be elaborated and explained descriptively as the following.

First component, the Input covers the element of selecting the right teachers with certain characteristics. The six experts agreed that teacher matters should be conversed earlier than student matter, especially in terms of selection of teachers and teacher's traits. Zulkifli totally agree that teacher matter should be the main priority before the students; "discuss about teachers first, not discuss about students. So, development of teachers is crucial. Therefore, in developing the teachers, of course there are many important things".

This claim has been supported by Danial, in his statement, "so I thought about how to get started, this is a good chance. So, first of all, of course the educator. Educators, educators first. That's right. I agree, educator. Without denying the role of the students. But if the educator, his concept of mind is incorrect, does not understand what Ulul Albab is, what content to have to produce Ulul Albab's student, he does not see".

Zulkifli, therefore, argue that the issue of teacher's selection is very important. He claims "The teacher's selection is a very good thing. I observe, any school or university, where they play good job, which affects and presume the other teachers, it will result extraordinary students. But, if the teacher is weak, then, the ability for his pupils to succeed with excellent is low. It is important. So, assembling the expertise of the teacher with a high spirit and having a solid sincerity, will produce outstanding students". Danial added that, to be selected as Ulul Albab teachers, they should not only experts in their field but it is compulsory for them to understand Islam. "lecturers or teachers first, in general, 
INTERNATIONAL JOURNAL OF ACADEMIC RESEARCH IN BUSINESS AND SOCIAL SCIENCES Vol. 8, No. 10, Oct. 2018, E-ISSN: 2222-6990 @ 2018 HRMARS

including those who are in fields of science or mathematics, generally understand the basic of Islam, compulsory".

Special characteristics should be addressed due to the respect of the given term in the AlQuran. It is therefore, selecting the right teachers with specific criteria for Ulul Albab program is very important and it is the most difficult part in developing a program according to Malik Badri, "I think that this is the most difficult part of the system of Ulul Albab. Who is the right teacher? The right teacher should have about 4 or 5 characteristics. The first one is ikhlas. He is really sincere. Sincerely wishes to be the teacher or counsellor with the aim of of Ulul Albab. The second one is for him to train himself to be one of Ulul Albab, because there is spiritual element".

Mat Rofa also agree with Malik Badri in which the teacher should have the quality that is able to train himself to be an Ulul Albab. And he reconfirms his statement, "so, the process of Ulul Albab is for the teachers themselves to reach to the students, the same message. And that process is what is meant by Ulul Nuha wa Ulul Absor and the Ulul Albab". Researcher, "To be a great Ulul Albab teacher, he must be a Ulul albab too?" Mat Rofa, "yes"

Thus, teachers who are going to teach Ulul Albab students according to Hashim Musa need to have good value as a teacher, "meaning, the teachers should have the value (good value), by then, what he delivers will bring effect of changes (differences)". Kamal Hassan also agree with that, "how do we get the teachers, teachers with that commitment can make a big different, despite the fact that they might be teaching in secular environment". Putting it in a more general sense, he further claims that professionals, including teachers who train to use their wisdom thought according to Allah's will be claimed as Ulul Albab, "here I agree too, meaning the scientist and scholars in various fields who use their aql (mind) given by Allah with correct (wise) use, it is Ulul Albab"

The selection which is made based on certain criteria could be a reflection of Ulul Albab characteristics. The characters or criterion that have been mentioned or suggested by the experts should be the yardstick or starting point to train and mould the fine character of Ulul Albab teachers. Therefore, the second component should come along right after discussing the issues inside the first component.

Second component is the Process or Mechanism which covers element of teachers' training and learning environment. The teachers' professional development program will not be effective unless a complete system for teacher preparation designed and properly implemented through integrating all the important elements (Ahmed Shami, 1990) of Ulul Albab. It is necessary to have a clear concept of excellence in its own teacher (Baloch, 1990). From the findings, there is enormous agreement among the experts that teachers should understand and comprehend the concept of Ulul Albab before they are able to educate the students. Thus, training program is crucial to introduce the concept, whereby, the important elements of Ulul Albab could be transferred to and absorbed by the teacher accordingly. According to Zulkifli, teachers should understand, envision, and acknowledge the concept of Ulul Albab in order to shape and mould students with Ulul Albab quality, "I mean, we want Ulul Albab generation, we chanted and we called it, we sought and we aimed it. But, the biggest point that thwarts it is because we do not provide teachers who understand and appreciate, acquaint and know about Ulul Albab. So, the thing is that he will not feel the sweetness or comfortable with 
INTERNATIONAL JOURNAL OF ACADEMIC RESEARCH IN BUSINESS AND SOCIAL SCIENCES

Vol. 8, No. 10, Oct. 2018, E-ISSN: 2222-6990 @ 2018 HRMARS

the will of Ulul Albab. Then, it becomes a separated entity. Therefore, the pupils who is expected to reach Ulul Albab, he gets nothing"

Kamal Hassan also clearly argue that the teacher of Ulul Albab program should be trained according to the concept of Ulul Albab, should be clear about its mission and vision, as it leads to what kind of generation is wanted for the society, "Like teacher training institution; what is the mission and vision? How about the teachers? So, now it is related to Malaysian education strategies (to) produce students with six aspirations. (Thus) we (need to) train the teachers for what kind of education. We start from there; it is how we educate teachers according to the concept of ULul Albab".

This is supported by Hashim Musa who agreed that teachers' institution should prepare specific element for the teachers of Ulul Albab. The professional development program, according to him is a better place to train teachers to understand the concept of Ulul Albab. He also mentioned this for two phases of professional development; pre-service and in-service program as a preparation for the teachers, "At the teachers' institution, now, it is good to train to sustain Ulul Albab in the character. Meaning, teachers' institution, new teachers in a faculty should embark Ulul Albab. And, for the teachers who not ever have that, then prepare for in-service course. Both in a shot, what we called as two-edge sword".

Ulul Albab program as laid down by the Ulul Albab concept in the Al-Quran is based on the devotion to the Almighty Allah and the observance to the creation of the Universe. As the experts agreed, based on Surah al-Imran:190-191, the elements of zikr (remembering Allah), fikr (thinking/thought) and taddabur/iktiraf (contemplate) should become the most important elements for both Ulul Albab program and Ulul Albab Teachers' Professional Development Program. Kamal Hassan in his statement, "want to understand what is this Ulul Albab, because it is a model that Allah indicates in the Al-Quran. We need to the model. They are combination of zikr, fikr and taddabur. Zulkifli also stresses these elements as concept of Ulul Albab, in his sayings, "meaning, Zikr, adding up with Fikr will result to the Iktiraf (contemplation) and pledge that would be brought to the Makrifah (gnosis or direct knowledge of Allah) and also Iman, which is at the end we paray, we humbly servitude to Allah. From there, we see the concept of Ulul Albab. According to Malik Badri, these elements are very important to train teachers with Ulul Albab characters. The second one is for him to train himself to be one of Ulul Albab, because there is spiritual element. A person of Ulul Albab will have to teach Ulul Albab, will have to be trained himself. He further said, "So it is important, this for teacher of Ulul Albab to bind himself with certain zikr and fikr, you see..and repeating the same words, the same tasbih, you know this repetition is very important". Mat Rofa also totally agrees that these elements need to be brought in into the system, "firstly, in a research regarding teachers or schools or education, it is a must to have the main two characters (elements); thinking (fikr) and zikr. Thinking as what we call in science and today's technology is a thought,, cognitive in all five thinking aspects. But it needs to combine with the Zikr. Supported by Danial, "the Ulul Albab has two main characteristics which is first Zikr, and Fikr. Revealed first, Zikr first. Then combine (joint) with inquiry, wayatafakkaru, use brain, analyse, brought to conclusion. All the teachers must have these two elements, integrated". As according to Hashim Musa, the thinking will bring the person to knowledge and the knowledge makes the person possesses values of Ulul Albab people, "Ulul Albab is those who thinking, knowledgeable. Knowledgeable person is civilized, virtuous, pious and practical. That is our 
INTERNATIONAL JOURNAL OF ACADEMIC RESEARCH IN BUSINESS AND SOCIAL SCIENCES Vol. 8, No. 10, Oct. 2018, E-ISSN: 2222-6990 @ 2018 HRMARS

aim. Recognize the true knowledge.. the true knowledge that bring to to direct knowledge of Allah, makrifatullah"

Besides that, the experts believe that integration of knowledge and learning environment should be put into concern in order to expose and prepare the teachers with balance personality. Kamal Hassan urges the Islamization of knowledge in purpose of reinterpreting the knowledge according to Quranic perspective, whereby, secularization is aimed to isolate rather than integrate. He said, "teaching and learning based on aqli and naqli knowledge, so I am emphasizing these things. Meaning, science or nature should be learnt according to the worldview of Al-Quran. Teachers should be realized that we become a slave of secularization. They do not see on how science has been taught in term of secular worldview could deny the truth, the truth of Allah's existence". Supported by Mat Rofa, "we, actually, we do not know that we are not integrated. meaning, science cannot derived by religion". Mat Rofa suggested that in order to preserve the value of Ulul Albab accordingly, especially from secularism or positivism influences. he urgently calls for integrative program that encourage holistic and Islamic values into the said program. The teacher we trained, we hope this process will take place continuously. If there is discussion among teachers, I hope that the awareness is widespread. Because we really do not know that we are not integrated. We do not know that we are now tied to positivism. Therefore, it is crucial to have a serious discussion regarding knowledge matters. As according to Zulkifli, "for me, the strength of knowledge is very important. Number 2, we not really expose it to the students that we called as Understanding. So, when we talk (about) Ulul Albab, do not look in terms of zahir (external/outward) only, do not just look (internal/inward). but (we want) a tremendous development. Mat Rofa added that "the impact of the knowledge should reach the students. When we say about complete understanding, it means that we want to deliver the knowledge with the values. Similar to what Hashim Musa claims, "even he teaches language, but bring in religious norms. Bring in the values (hati budi) of Malay people, Malay character.

From the discussion above, it is clearly shown that the concept of Ulul Albab should be addressed properly in the Process stage, whereby, the two main elements of Ulul Albab, zikr with fikr would be acting as a masterpiece to ensure the program is in the right track. In addition, integrating the teachers with several knowledges is another category that would help the teachers to cater to the needs of Ulul Albab students in the future.

The third component is the Outcome. It covers the consequences of the teachers of Ulul Albab program. It counts the result of confronting the first and second components of the theory. Begin with thorough selection and sufficient process, by then, an outcome is expected to present. From the findings, there are two aspects that have been talked about consistently by the experts regarding the nature of teachers' professional development of Ulul Albab program, in which the teachers would have; Ulul Albab character, and integrated/ holistic personality

First nature: The Teachers would have the Ulul Albab character. After the teacher understand the concept of Ulul Albab and go through some process. According to Zulkifli, "(it may) procreate teachers who understand, and completely understand, personified, and knowledgeable (experts) about Ulul Albab. As Kamal Hassan clearly mentions, "because at the end of the day, will see the Ulul Albab as his character. After he did the scientific research, and then what he said oo my Lord, you have not created this for nothing". And supported Malik Badri believes that by understanding the 
concept of Ulul Albab, one would be able to train themselves to be an Ulul Albab, resulting in turning himself into an Ulul Albab.." So it is important, for teachers of Ulul Albab to bind himself with certain zikr, zikr and fikr, you see. The importance of contemplation, meditation and how we can improve an iman, makes a person to become closer to become Ulul Albab"

Second nature: The Teachers would have an integrated/holistic personality. Malik Badri, somehow, categories Ulul Albab characters into three holistic elements, namely cognitive, practical, and emotional, "so these unless the person should perfect the three aspects, he cannot be Ulul Albab. you see. (it must be holistic?) yes, cognitive, practical, and emotional. According to Mat Rofa, teachers could have the character if he completely understands the concept of Ulul Albab which brings him closer to devoting himself for Allah, "this Ulul Albab, it has the teaching and learning process. First is for ourselves, firstly, it is for us to completely understand Ulul Albab. In this contexts, if Ulul Albab, he will reach to God. Danial believes that, teachers who have both the knowledge, aqli and naqli are required for Ulul Albab program, as he mentioned that science and religious teachers should integrate their knowledge. "science teacher, good subject, but he needs to understand religion. At the same time, to produce someone in religious department, the ustaz and ustazah need to have basic science. Therefore, it really necessary to have a system that enable teachers to blend themselves with various field of knowledge especially, naqli and aqli knowledge. As according to Danial, "if a person (a teacher) enhances two (knowledge), he flows smoothly, beautiful, both are coming, it gels.

These three components have been formulized into a diagram (figure 1) below in order have a clear perspective on the foundation of Ulul Albab Teachers' Professional Developemnet Programme Theory (TPDP). 


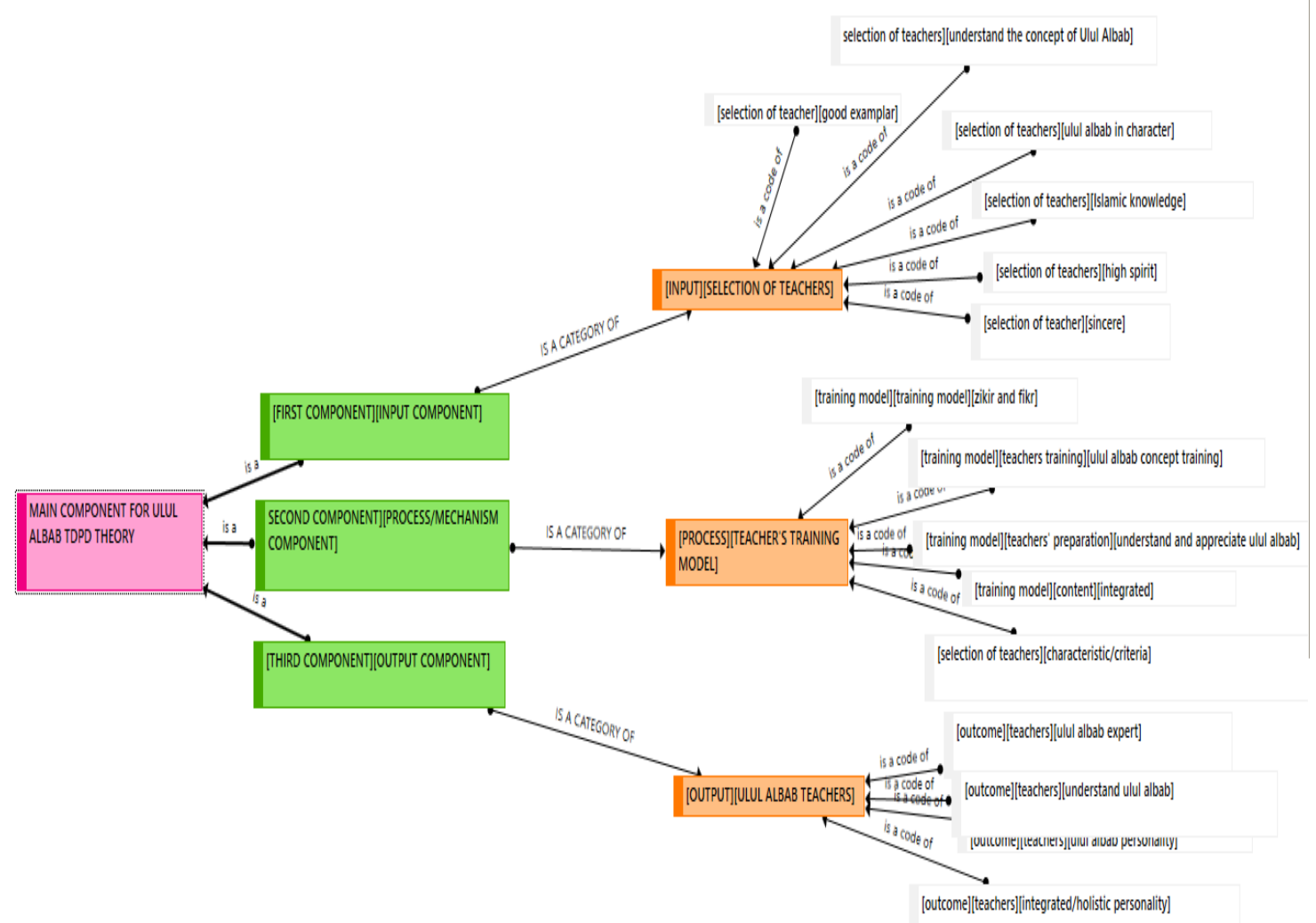

Figure 1: Three Main Components for Theory of Ulul Albab TPDP

\section{CONCLUSION}

Teachers are indisputably their students' exemplars. Obviously, students acquire the good traits and virtuous behaviour from their teachers who give guidance and penetrate into their hearts. On that account, teachers must over disciplined themselves and trained on virtuous and noble manners to be the best exemplars for their students. Therefore, professional development is important to comprehensively addresses teachers preparatory towards proper professionalism. Ulul Albab TPDP is aimed to provide in-depth professional development for teachers with the goal of providing rigorous, highly supported integrated education opportunities for Ulul Albab students to simultaneously become Ulul Albab professionals and experts in various fields. Grounded in a model of apprenticeship, Ulul Albab TPDP theory emphasizes multilayered and sustainable building of Ulul Albab teacher expertise. Thus, the three main components, namely, the Input, the Process/Mechanism, the Output have been drawn up to discover crucial elements in order to develop a theory for Ulul Albab Teachers' Professional Development. Teachers' Professional Development program/training for Ulul Albab program is seen to have a serious and specific role specifically to generate Ulul Albab students in the country. As mentioned above, sufficient and competent teachers should be produced; who are competent enough to uphold the responsibilities, not only merely teaching but moulding Ulul Albab characters into their students. In order to tackle the current situation, it is necessary to investigate, examine and refine the crucial components that addresses specific Professional Development (PD) element for teachers of Ulul Albab program. 
INTERNATIONAL JOURNAL OF ACADEMIC RESEARCH IN BUSINESS AND SOCIAL SCIENCES

Vol. 8, No. 10, Oct. 2018, E-ISSN: 2222-6990 ㄷ 2018 HRMARS

\section{Corresponding Author}

Nor Adzimah Subirin, Faculty of Educational Studies, University Putra Malaysia, 43400 UPM

Serdang, Selangor Darul Ehsan, Malaysia. Email: noradzimahd@gmail.com

\section{References}

Abdul Ghafur C. (1980). Recontruction of Curriculum for the Muslim Teacher. In M.H Al-Afendi \& N.A Baloch (Eds), Curriculum and Teacher Education (pp.192-208). London: Hodder \& Stoughton.

Shami, A. (1980). A System for the Preparation of Muslim Teachers. In M.H Al-Afendi \& N.A Baloch (Eds), Curriculum and Teacher Education (pp.155-160). London: Hodder \& Stoughton.

Arshad, A. M. (2015). Ulasan sistematik program Ulul Albab dalam sistem pendidikan di Malaysia. Jurnal Kurikulum \& Pengajaran Asia Pasifik. 3(4), 22-35.

Baloch, N.A. (1980). Curriculum and Teacher Education, London: Hodder \& Stoughton.

Böhm, A. (2004). Theoretical Coding: Text Analysis in Grounded Theory. In U. Flick, E. Kardorff \& I. Steinke (Eds.), A Companion to Qualitative Research (pp. 270-275). London: Sage Publication.

Charmaz, K. (1983). The grounded theory method: An explication and interpretation. In: Emerson, R. M. (ed.). Contemporary field research. pp. 109-126. Prospect Heights, IL: Waveland Press.

Creswell, J.W. (2003). Research design: Qualitative, quantitative and mixed methods approaches. Thousands Oak: SAGE Publications.

Guskey, T. R. (2000a). Evaluating professional development. Thousand Oaks, CA: Corwin

Guskey, T. R. (2002). Professional development and teacher change. Teachers and Teaching: Theory and Practice. 8(3/4), 381-391

Hassel, E. (1999). Professional development: Learning from the best. Oak Brook, IL: North Central Regional Educational Laboratory (NCREL)

Halim, L. (2011). Ilmu Pedagogi Kandungan Sains untuk Pendidikan Bersepadu. In Khalijah Mohd (Ed), Pendidikan Sains Berteraskan Tauhid (150-166). Penerbit UKM

Hassan, M. K. (2010). The return to the Qur'anic paradigm of development and integrated knowledge: The Ulul Al-Albab model. Intelectual Discourse. 18(2), 183-210.

Shahril, M. (2013). Integrating Ulul Albab education and Science education in development insan ta'dibi generation: A case study of MARA Junior Science College (MJSC). Kertas kerja yang dibentangkan di International Academic Conference pada 14 -16 Januari 2013 di Antalya Turki.

Nabil, N. (2000). Al-Ghazali (A.D. 1058-1111; A.H. 450-505): The quarterly review of comparative education. Paris, UNESCO: International Bureau of Education), vol. XXIII, no. 3/4, 1993, p. 519542.

Alwi, N. H. H. (2002) Pembentukan Model Pembangunan Insan Kamil Dalam Pengajaran Sains. Tesis Dr. Fal. Universiti Kebangsaan Malaysia

Alwi, N. H. H. (2011). Falsafah bina Insan Kamil: Integrasi Pendidkan Sains dan Agama.. In Khalijah Mohd (Ed), Pendidikan Sains Berteraskan Tauhid (99-147). Penerbit UKM

Stacey J. (2005). Why Is Professional Development So Important?. Southwest Educational Development Laboratory, p.1. 
Strauss, A. and Corbin, L (1990). Basics of Grounded Theory Methods. Beverly Hills, CA: Sage.

The interview with Tan Sri Profesor Dr Kamal Hassan on 24 August 2016 at CENTRIS Universiti Islam Antarabangsa Malaysia.

The interview with Datuk Dr Zulkifli Mohd Al-Bakri on 4 November 2016 at Pejabat Mufti Wilayah Persekutuan Kuala Lumpur.

The interview with Professor Dr Malik Badri on 21 February 2017 at Universiti Islam Antarabangsa Malaysia.

The interview with Dr Mat Rofa Ismail on 16 March 2017 at INSPEM, Universiti Putra Malaysia. The interview with Datuk Dr Danial Zainal Abidin on 1 April 2017 at Klinik Syifa, Pulau Pinang. The interview with Prof Emeritus Dr Hashim Musa on 11 April 2017 at Faculty Modern Language and Communication, Universiti Putra Malaysia.

UNESCO (2003). 23th General Conference: Final Communiqué of the Ministerial Round Table Meeting, 4 October 2003. http://www.unesco.org. 